Agro-Science Journal of Tropical Agriculture, Food, Environment and Extension Volume 20 Number 2 (April 2021) pp. $68-73$

ISSN 1119-7455

\title{
MARKETING, DISTRIBUTION AND CONSUMPTION OF FISH IN IDO LOCAL GOVERNMENT AREA, OYO STATE, NIGERIA
}

\author{
${ }^{* 1}$ Azeez F.A., ${ }^{2}$ Kabir G.B., ${ }^{1}$ Amoo M.A. and ${ }^{2}$ Nosiru M.O. \\ ${ }^{1}$ Federal College of Forestry, PMB 5087, Jericho Ibadan, Oyo State, Nigeria \\ ${ }^{2}$ Forestry Research Institute of Nigeria, PMB 5054, Jericho Ibadan, Oyo State, Nigeria \\ *Corresponding author’s email: fazeez2013@gmail.com
}

\begin{abstract}
Like other developing countries, Nigeria faces a lot of problems confronting fish marketing such as dwindling profit due to fish spoilage as post-harvest losses occur more frequently particularly in the rainy reason, lack of improved technology for the management of fish production, inefficient harvesting methods and wastefulness due to lack of infrastructural facilities. This study assessed fish marketing, distribution and consumption in Ido Local Government Area (LGA), Oyo State, Nigeria. A two-stage random sampling technique was used while descriptive statistics (frequency distribution and percentage frequencies) and inferential statistics (such as multiple regression analysis and budgetary analysis) were used for the analysis. The study concluded that fish marketing was a profitable business though with a small profit margin. The study thus recommended that micro lending programmes should be given a needful attention and priority to increase the entrepreneurs' income and bring about a massive economic prospect for Ido LGA in particular and Oyo State Nigeria in general.
\end{abstract}

Key words: constraints, consumption, determinant, fish, marketing, profit

\section{INTRODUCTION}

Fish is a vital source of good quality protein needed in human diets. It has the highest level of easily metabolizable protein, fats, vitamin, calcium, iron and essential amino acids when compared to other sources of animal protein such as poultry and beef. Fish is important to the ever-increasing world population, especially in most parts of Africa, as it is the major source of cheap, high quality and most affordable animal protein, contributing $50-60 \%$ of the animal protein intake of the population especially in rural communities (Ayoola, 2010).

There is rising need for protein in human diet due to rising growth in population. The tropical regions mostly in developing nations require more protein so as to supply the essential nutrients which are lacking in other diets. Fish consumption has no restriction within diverse religious groups, unlike the eating of dog and pork that is forbidden in Islam (Agbelege and Ipinjolu, 2013). In addition, fish marketing is an essential aspect of fish production because the essence of production is mainly to reach the end consumers. So, marketing is described as all processes involved from the point of production of a commodity till it reaches the final consumer. Marketing is thus regarded as an integral part of socio-economic lives of the local people in connection with their production system (Agbelege and Ipinjolu, 2013).
According to Olukosi et al. (1990), marketing of fish could be considered as the performance of all commercial activities involved in the movement of fish from the harvest point (fisherman or fish farmer) to the final consumer. Marketing of fish does not take place between fisherman and consumer alone because there are numerous middlemen involvement within the link. Therefore, price of fish becomes unstable depending on the level and mode of involvement of such middlemen within a particular period of time (Olukosi et al., 1990).

As fish and fishery products are highly traded commodities, fish production is a necessary part of marketing process. Marketing fish and fish products in Nigeria starts from the harvesting stage to the value chain where it then gets to the final consumer. Both men and women play key roles in marketing and distribution of fish in Nigeria (Atanda, 2009).

Efficient marketing system is significant in a country under all conditions and at all its development stages. Therefore, effective marketing system will locate areas of surpluses and link them to areas of shortages. The marketing relationship between fish traders and fishermen is often long-lasting, providing an assured market outlet to the small-scale artisanal fishermen and a source of steady supply to the trader. Marketing plays a vital role in a market economy and its role as an incentive to fish rearing and productivity cannot be over emphasized (Olukosi et al., 1990). 
However, it is worthy of note that the lesser familiar a species is, the lower the acceptability or the demand. People's tastes are formed slowly and strongly influenced by traditional eating habits. Likewise, the higher the prices of fish species, the lower the demand and vice versa because poor people usually prefer cheaper substitutes. In developing countries like Nigeria, a lot of problems confront fish marketing such as dwindling profit due to fish spoilage as post-harvest losses occur more frequently particularly in the rainy reason, lack of improved technology for the management of fish production, inefficient harvesting methods and wastefulness due to lack of infrastructural facilities (Nwabunike, 2015).

Furthermore, poor production and marketing policies, unhealthy rivalry among traders, poor transportation network, tribalism and ethnicity among others were also identified as challenges facing fish marketing in Nigeria (Nwabunike, 2015). Since proper marketing of fish ensures that fish is made available to all and sundry, it therefore becomes imperative that assessment of fish marketing be carried out to determine the viability and effectiveness of marketing system of fish. Considering the significance of the fish in the local economy, and likely impacts on the earnings of local fish marketers as a result of marketing upheaval, this paper seeks to answer the following questions: (i) what are the factors influencing fish marketing in the study area? (ii) What are the constraints associated with fish marketing? (iii) What are the marketing distribution channels adopted by the fish marketers and (iv) how much is the cost of production and supply of fish, the revenue and the marketing margin obtainable in the study area?

\section{MATERIALS AND METHODS Area of Study}

Ido is a local government area (LGA) in Oyo State, Nigeria. Its headquarters is in the town of Ido. It has a land area of $986 \mathrm{~km}^{2}$. As at 2019 when the study was executed, population stood at 143,533 , a value being a projection from the 2006 population figure. Ido LGA covers the area spanning Apata, Ijokodo, Omi-Adio, Akufo and Apete. This LGA shares boundaries with Oluyole, Ibarapa East, Akinyele, Ibadan South-West and Ibadan North-West LGAs in Oyo State and also with Odeda LGA in Ogun State.

The council formerly has six wards, which had been increased to ten for easy exercise of franchise. Among the major towns within the GA are Ijokodo, Ido, Omi-Adio, Apata, Apete, Akufo and Bakatari as well as about 612 villages which include Ogunweide, Dada, Olowofela, Apooyin, Oderemi, Odetola, Erinwusi, Tade, Alagbaa, Iku- senla among others. On the account of extensive fertile soil, which is suitable for agriculture, the basic occupation of the people is farming. There are large hectares of grassland which are suitable for land and aquatic animal domestication, vast forest reserves and rivers. People in the area grow varieties of cash crops such as cocoa, kola nut, palm oil, timber and food crops such as maize and rice. The area is also suitable for a wide range of edible fruits.

\section{Sampling Procedure and Sample Size}

The study utilized a two-stage random sampling technique. In the first stage, simple random sampling technique was used to select four towns (namely: Apata, Omi-Adio, Ijokodo and Apete) out of twelve major towns in Ido LGA. In the second stage, 25 respondents from the four towns were randomly selected in each town totaling one hundred respondents. In this survey, the respondents were household heads who engage in fish marketing. Moreover, the questionnaire had detailed questions on socio-economic characteristics of the marketers (such as age, sex, level of education, etc), marketing experience, marketing channels and problems associated with fish marketing as well as factors influencing fish marketing in the study area. The survey data were obtained for the year 2019, and it was based on one-year recall period. All the 100 questionnaires distributed to the sample respondents were retrieved, and hence, findings of this study are based on 100 respondents. The survey was carried out between March 2019 and November 2019.

\section{Data Analysis}

Descriptive statistics (which included frequency distribution and percentage frequencies) and inferential statistics (such as multiple regression analysis and budgetary analysis) were used to analyze the data for this study.

\section{Model Specification}

\section{a. Regression model}

Multiple regression models were used to determine the influence of socioeconomic factors, purchase price and other marketing costs on the fish marketing margin. The model can be explicitly stated as:

$$
\mathrm{Y}=\mathrm{f}\left(\mathrm{X}_{1}, \mathrm{X}_{2}, \mathrm{X}_{3}, \mathrm{X}_{4}, \mathrm{X}_{5}, \mathrm{X}_{6}, \mathrm{X}_{7}, \mathrm{X}_{8}, \mathrm{X}_{9}, \mathrm{e}\right) \ldots \text { (1) }
$$

where $Y$ is marketing margin, $b_{i}$ is intercept, $b_{2}$ is the slope (co-efficient), $\mathrm{X}_{\mathrm{i}}$ is a vector of explanatory variables and is described as follows: $X_{1}$ is age of respondent (in years), $X_{2}$ is level of education (formal education $=1$, non-formal education $=0$ ), $\mathrm{X}_{3}$ is gender of the respondents (Dummy: $1=$ male; $2=$ female), $X_{4}$ is access to credit facilities (credit is available $=1$, credit is not available $=0), \mathrm{X}_{5}$ is membership of association (membership $=1$, nonmembership $=0$ ), $X_{6}$ is lack of capital, (capital is available $=1$, capital is not available $=0$ ), $X_{7}$ is high cost of production (in Naira), and $e$ is error term. Following Olayemi (1998), the relationship between the endogenous variable and each of the exogenous variables were examined using linear, exponential, semi-log and double-log functional forms. The lead equation was chosen based on the coefficient of 
determination $\left(\mathrm{R}^{2}\right)$ value, statistical significance and economic theory that support fish marketing.

The equations of the functional forms are also specified. Four functional forms were fitted into the analysis, the models being: linear, exponential, double- $\log$ and semi-log functional forms:

Linear: $\mathrm{Y}=\mathrm{b}_{0}+\mathrm{b}_{1} \mathrm{X}_{1}+\mathrm{b}_{2} \mathrm{X}_{2}+\mathrm{b}_{3} \mathrm{X}_{3} \ldots++\mathrm{b}_{9} \mathrm{X}_{9}+\mathrm{e}$

Semi-log: $\mathrm{Y}=\log \mathrm{b}_{0}+\mathrm{b}_{1} \log \mathrm{X}_{1}+\mathrm{b}_{2} \log \mathrm{X}_{2}+\mathrm{b}_{3} \log$ $\mathrm{X}_{3} \ldots++\mathrm{b}_{9} \log \mathrm{X}_{9}+\log \mathrm{e}$

Exponential: $\log \mathrm{Y}=\mathrm{b}_{0}+\mathrm{b}_{1} \mathrm{X}_{1}+\mathrm{b}_{2} \mathrm{X}_{2}+\mathrm{b}_{3} \mathrm{X}_{3} \ldots++$ $\mathrm{b}_{9} \mathrm{X}_{9}+\mathrm{e}$

Double-log: $\log \mathrm{Y}=\log \mathrm{b}_{0}+\mathrm{b}_{1} \log \mathrm{X}_{1}+\mathrm{b}_{2} \log \mathrm{X}_{2}$ $+b_{3} \log X_{3}++b_{9} \log X_{9}+\log \mathrm{e}$.

\section{b. Budgetary technique}

The budgetary technique which involves the cost and return analysis was used to determine the Marketing Margin (MM) of the respondents. The model specification is given as:

$$
\mathrm{GM} \%=\mathrm{TR}-\mathrm{TC} \div \mathrm{TR} \times 100
$$

where GM is gross margin as a percentage, TR is total revenue $(\mathrm{N})$ (price $/ \mathrm{kg} \times$ the quantity sold), and TC is total cost $(\mathrm{N})$, consisting of the cost of purchase in month, the cost of storage in Naira per month and the cost of transportation in Naira per month, facilitating cost, and cost of labour per month.

\section{RESULTS}

The study identified among other things different types of fish that were available for the marketers in the study area. Though, other types of fish may be sold occasionally but their availability depends on seasonality. So, the most common types of fish in terms of availability and accessibility by the fish marketers regardless of seasonal characteristics include: Kote (horse mackerel) (14\%), Panla (blue whiting) (15\%), Shawa (herrings) (18\%), Alaran $(17 \%)$, Tilapia (14\%), Sardine $11 \%$ and Titus $(11 \%)$. Aside this taxonomic identification, that the exponential functional form provided the lead equation of the factors that affect marketing of fish in the study area. Apart from the fact that its coefficient of multiple determination $\left(\mathrm{R}^{2}\right)$ is higher than those of the linear, double log and the semi-log forms, the exponential form was chosen because it has the least standard error as well as one of the highest number of statistically significant ( $p$-value). Table 1 reflects the determinants of marketing margin of fish in the study area. Majority of the marketers sold fresh fish while some of them processed different types of fish into another forms (such as smoking, sun drying, frying, salting) before they could be offered for sale.
Factors Influencing Variation in Marketing Margin The regression analysis was used to predict the influence of the hypothesized explanatory variables on the marketing margin (profitability indicator). The results of ordinary least squares multiple regression are presented in Table 1.

Based on the analysis from the exponential function, the result shows that $73 \%$ of the variation in the factors affecting marketing of fish in the study area was explained by the exogenous (independent) variables included in the model. The study shows that there was a significant $(p<0.05)$ relationship between participation in fish marketing and the age, household size, access to credit facilities, cost of production, and education of the fish marketers.

\section{Constraints Associated with Fish Farming}

The study identified some of the constraints associated with fish marketing in the study area. The result showed that $38 \%$ of the fish marketers strongly agreed that poor sales price was negatively affecting their sales while about $34 \%$ of them agreed with same. In addition, $42 \%$ strongly agreed that high cost of production was a constraint as $25 \%$ of them agreed with same and half $(50 \%)$ of the fish marketers agreed with the fact that they experienced low patronage while $17 \%$ of them strongly agreed with the same. Also, $59 \%, 63 \%, 57 \%, 61 \%, 56 \%$ and $63 \%$ of the fish marketers identified insufficient fund, poor handling, packaging and processing facilities, lack of capital, inadequate storage facilities, lack of price stability and small enterprise with low earnings respectively as series of constraints they were facing in both agreed and strongly agreed categories (Table 2).

\section{Marketing Price}

This section presents the market price of different types of fish in the study area. Findings indicated that the average minimum cost price of fish in the study area was $¥ 600$ per $\mathrm{kg}$ while the average maximum price was 900 per $\mathrm{kg}$. Table 3 thus

Table 1: Determinants of marketing margin

\begin{tabular}{lcccc}
\hline Intercept & $\begin{array}{c}\text { Linear } \\
\text { function }\end{array}$ & $\begin{array}{c}\text { Exponential } \\
\text { function }\end{array}$ & $\begin{array}{c}\text { Double } \\
-\log \end{array}$ & $\begin{array}{c}\text { Semi-log } \\
\text { function }\end{array}$ \\
\hline Constant & 2.094 & & & \\
$\mathrm{X}_{1}$ & 0.12 & 5.22 & -2.30 & 6.93 \\
& $(0.27)$ & $(0.01)^{*}$ & $(0.19)$ & $(0.02)^{*}$ \\
$\mathrm{X}_{2}$ & -0.28 & -2.26 & -0.96 & 0.03 \\
& $(0.82)$ & $(0.02)^{*}$ & $(0.35)$ & $(0.97)$ \\
$\mathrm{X}_{3}$ & 1.11 & -1.19 & 0.35 & -2.39 \\
& $(0.28)$ & $(0.16)$ & $(0.71)$ & $(0.13)$ \\
$\mathrm{X}_{4}$ & 0.05 & 2.09 & 0.63 & -1.02 \\
& $(0.68)$ & $(0.02)^{*}$ & $(0.53)$ & $(0.48)$ \\
$\mathrm{X}_{5}$ & -0.61 & 0.94 & 0.86 & 1.27 \\
& $(0.06)^{*}$ & $(0.27)$ & $(0.33)$ & $(0.14)$ \\
$\mathrm{X}_{6}$ & 0.16 & -5.87 & -1.17 & 1.35 \\
& $(0.14)$ & $(0.02)^{*}$ & $(0.19)$ & $(0.39)$ \\
$\mathrm{X}_{7}$ & -2.22 & -1.57 & -0.01 & 3.71 \\
& $(0.03)^{*}$ & $(0.04)^{*}$ & $(0.22)$ & $(0.00)^{*}$ \\
$\mathrm{R}^{2}$ & 0.59 & 0.73 & 0.51 & 0.67 \\
$\mathrm{~F}-$ Value & 1.56 & 23.90 & 7.08 & 13.50 \\
$\mathrm{~N}$ & 100 & 100 & 100 & 100 \\
Std. error & 0.51 & 0.19 & 2.81 & 8754.00 \\
\hline Source: Field survey 2019 & \multicolumn{3}{c}{} \\
reflects the marketing price of fishes in Ido LGA.
\end{tabular}


Table 2: Constraints associated with fish marketing

\begin{tabular}{|c|c|c|c|c|}
\hline Constraints & Strongly Agree N (\%) & Agree N (\%) & Disagree N (\%) & Strongly Disagree N (\%) \\
\hline Poor transportation & $11(11.0)$ & $27(27.0)$ & $40(40.0)$ & $22(22.0)$ \\
\hline Lack of ready-made market & $22(22.0)$ & $24(24.0)$ & $25(25.0)$ & $29(29.0)$ \\
\hline Poor sales price & $38(38.0)$ & $34(34.0)$ & $18(18.0)$ & $10(10.0)$ \\
\hline Lack of labour & $22(22.0)$ & $21(21.0)$ & $27(27.0)$ & $30(30.0)$ \\
\hline High cost of production & $25(25.0)$ & $42(42.0)$ & $30(30.0)$ & $3(3.0)$ \\
\hline Lack of buyers & $18(18.0)$ & $30(30.0)$ & $43(43.0)$ & $9(9.0)$ \\
\hline Low patronage & $17(17.0)$ & $50(50.0)$ & $27(27.0)$ & $6(6.0)$ \\
\hline Insufficient fund & $24(24.0)$ & $35(35.0)$ & $23(23.0)$ & $18(18.0)$ \\
\hline Poor handling, packaging \& processing facilities & $21(21.0)$ & $42(42.0)$ & $35(35.0)$ & $2(2.0)$ \\
\hline Lack of capital & $21(21.0)$ & $36(36.0)$ & $38(38.5)$ & $5(5.0)$ \\
\hline Inadequate storage facilities & $24(21.0)$ & $37(37.0)$ & $27(27.0)$ & $12(12.0)$ \\
\hline Price instability & $24(24.0)$ & $32(32.0)$ & $30(30.0)$ & $14(14.0)$ \\
\hline Small enterprise with low earnings & $32(32.0)$ & $31(31.0)$ & $26(26.0)$ & $11(11.0)$ \\
\hline Membership of association's bureaucracy & $12(12.0)$ & $27(27.0)$ & $41(41.0)$ & $17(17.0)$ \\
\hline
\end{tabular}

Source: Field Survey, 2019.

Table 3: Marketing price of fishes

\begin{tabular}{|c|c|c|c|c|c|}
\hline Market prices of fishes ( & Minimum price & Maximum price & Average price & Standard Deviation & Range \\
\hline Cost price of fishes & 600 & 900 & 757.9 & 59.2 & 300 \\
\hline Selling price & 750 & 950 & 855.5 & 57.3 & 200 \\
\hline Cost of transportation per month & 00.00 & 1000 & 95.00 & 240.2 & 1000 \\
\hline Cost of facilitating fishes supply & 00 & 3000 & 109.6 & 319.8 & 3000 \\
\hline Cost of storage per month & 00 & 37000 & 9808.4 & 57.24 & 37000 \\
\hline Cost of labour & 00 & 7000 & 1703 & 9327 & 7000 \\
\hline Average sale per month per $\mathrm{kg}$ of fishes & 900 & 1100 & 1000 & 47.9 & 1000 \\
\hline
\end{tabular}

Source: Field Survey, 2019

\section{Marketing Channels}

Table 4 describes marketing channels adopted by the fish marketers in the study area. In terms of the sources of fish supply, it can be deduced that most fish marketers $(64 \%)$ stocked their fish from the middlemen while $36 \%$ stocked theirs directly from the producers (fish farms). In the same vein, the marketing channel that most of the fish sellers (65\%) adopted was retail trade while $36 \%$ practiced wholesales marketing system, two percent of the fish marketers were commissioned agent. More so, for every 10 marketers, 6 waited for customers to come and buy fish in their shop, $8 \%$ used to engage in home delivery, $6 \%$ used to sell fish through sales representatives while $27 \%$ indicated hawking as means through which they sell their fish.

Table 4: Marketing channels adopted by fish marketers

\begin{tabular}{|c|c|c|}
\hline Variables & Frequency & $\%$ \\
\hline \multicolumn{3}{|c|}{ Means through which marketers stock fish } \\
\hline Directly from producers & 36 & 36.0 \\
\hline From middle men & 64 & 64.0 \\
\hline \multicolumn{3}{|l|}{ Marketing system practiced } \\
\hline Wholesales & 36 & 36.0 \\
\hline Retail & 61 & 61.0 \\
\hline Commissioned agent & 2 & 2.0 \\
\hline Non-commissioned agent & 1 & 1.0 \\
\hline Farm gate middlemen & 0 & 0.0 \\
\hline \multicolumn{3}{|l|}{ How marketers deliver products } \\
\hline Customers coming themselves & 60 & 60.0 \\
\hline Home delivery & 7 & 7.0 \\
\hline Through sales rep & 6 & 6.0 \\
\hline Through hawking & 27 & 27.0 \\
\hline \multicolumn{3}{|c|}{ If the marketers adopt value addition for their products } \\
\hline Yes & 91 & 91.0 \\
\hline No & 9 & 9.0 \\
\hline \multicolumn{3}{|l|}{ Value addition methods adopted } \\
\hline Advertisement & 23 & 23.0 \\
\hline Package & 10 & 10.0 \\
\hline Price reduction & 11 & 11.0 \\
\hline Good customer relation & 56 & 56.0 \\
\hline
\end{tabular}

Also, majority (91\%) of the respondents adopted one or more value addition methods as a way of improving the fish marketing system. As regards the value addition method adopted, about 56\%, 23\%, $10 \%$ and $11 \%$ of the marketers indicated a good customer relation, advertisement, good packaging and price reduction, respectively as the value addition method they adopted.

\section{Marketing Margin}

The average cost price of fishes (stocking) in the market was $\$ 757$ per $\mathrm{kg}$. More so, the minimum selling price of fishes per $\mathrm{kg}$ by the marketers was $\$ 750$ while the maximum selling price was $\$ 950$. Findings further showed that the average selling price of fishes was 855 in the market. Also, the average turnover of the marketers per month was $\$ 855000$ $(\mathrm{N} 855 \times 1,000 \mathrm{~kg}$ of fishes). In the same vein, the average cost price per month (stocking cost) was $\$ 757,0001000-\mathrm{kg}^{-1}$. Transportation cost was one of the variable costs that determine the cost price of fish in the study area. Some marketers incurred a very little transportation cost per month probably because some of their customers used to picking their fishes themselves, hence, some costs were saved.

On the other hand, some marketers incurred a very huge transportation cost due to their locations to the market or market channels network. So, the average maximum cost of transportation was $\$ 1,000$ and the average price of transportation was $\$ 950$ per month. In addition, the average cost of facilitating fishes supply in the market was $\$ 3,000$ while the average cost of storage facilities per month was $\$ 9,808$ and the maximum cost of storing fishes per month in the market amounted to $\$ 37,000$. Likewise, the maximum cost of labour was $\$ 7,000$. In sum, all the running cost (TVC) amounted to $\$ 54,758$. So, the total cost (TC) per month was $\$ 811,758$ (i.e., TVC $\$ 54,758+$ stocking cost $\$ 757,000$ per $1,000 \mathrm{~kg}$ ). 
Table 5: Budgetary analysis of marketing margin

\begin{tabular}{|c|c|c|}
\hline Item & $\begin{array}{l}\text { Cost }(\aleph) \\
\text { per month }\end{array}$ & $\begin{array}{l}\text { Income ( } \\
\text { per month }\end{array}$ \\
\hline Storage & 37,000 & \\
\hline Labour & 7,000 & \\
\hline Logistics (e.g., calls, incentive & 950 & \\
\hline Transportation & 9,808 & \\
\hline Stocking of fish per $1000 \mathrm{~kg}$ & 757,000 & \\
\hline Total cost & 811,758 & \\
\hline Total Income & \multirow{3}{*}{\multicolumn{2}{|c|}{$\begin{array}{c}855,000 \\
43,242 \div 855,000 \times 100=5.057 \\
=0.057\end{array}$}} \\
\hline Gross Margin & & \\
\hline Profitability index & & \\
\hline
\end{tabular}

Therefore, the profit margin which is the total turnover (TR) minus the total cost (TC) ( $\$ 855,000$ $\$ 811,758$ ) was $\$ 43,242$. Likewise, the gross margin was $($ total revenue - total running cost $)=$ $\$ 855,000-\$ 54,758=\$ 800,242$.

\section{DISCUSSION}

The results of this study suggest that majority ( $82 \%)$ of the fish marketers in the study area were female which implies that female gender deals more in fish marketing as a means of supporting their family for their livelihood. Most of the fish marketers also have no formal education indicating that low level of education does not affect their interest in marketing of fish, contrary to Olagunju et al. (2007) that educated fish farmers usually do well in their businesses because they may be very receptive to innovations. Further, Shawa, Alaran, Panla and Kote, Tilapia, Sardine and Titus in that order are the common marketable types of fish in Ido LGA, Oyo State.

With regard to factors influencing variations in marketing margin among fish marketers in the study area, the relationship between marketing of fish and the level of education with cost of production was negative which implies that as these two policies driven variables increase, the rate at which the fish marketers sell their products reduces. This implies that non-educated entrepreneurs highly involved in fish marketing in the study area. Part of the reasons for this possibility might be due to the fact that most elites might not be favourably disposed to venturing into fish marketing considering the outdated and primitive ways of managing the business. Though Pala (1976) posited contrary evidence to the finding of this study where he argued that formal education is an important factor in the performance and management of fish marketing and fishery sector in general. With regard to high production cost, it is plausible to assume that high cost of production has tendency of lowering the sales of fish because of the possible reduced turnover. For instance, Babalola et al. (2015) identified high cost of preservation as a major constraint to sales of fish in Ogun State.

In addition, productive age of 35 and above was a significant predictor of fish marketing. That is, majority of the fish marketers are in their active age suggesting that the business has high sustainability tendency since it is dominated mostly by the youth (Babalola et al., 2015). Findings further showed that access to credit facilities is a driver of sustained participation in fish marketing in the study area.
In terms of marketing channels, some fish marketers stocked their fish from the middle men while some stocked theirs directly from the producers (fish farms). Although retail marketing was the most common channel adopted while $36 \%$ practiced wholesales marketing system, only $2 \%$ passed through commissioned agent. More so, for every 10 marketers, 6 waited for customers to come and buy fish in their shop, $8 \%$ used to engage in home delivery, $6 \%$ used to sell fish through sales representatives while $27 \%$ indicated hawking as the means through which they sell their fish. This outcome correlates with the findings of Omeje et al. (2020) who avowed similar result that the main fish buyers in Kainji Lake Basin of Nigeria were middlemen. That is to say that about $53.8 \%$ of the fish marketers buy and resell to others (processors, consumers, farmers, etc.). Likewise, the findings also showed that the majority $(91 \%)$ of the fish marketers adopted value addition method to their products as one tenth of them did not explore value addition to their product. Concerning the value addition method adopted, above half of the marketers indicated a good customer relation as the value addition method they used to adopt, $23 \%$ indicated advertisement as the value additional method they adopted, one-tenth of the fish marketers and $2 \%$ indicated package as the value additional method they adopted.

Further, in terms of constraints associated with fish marketing, majority of the fish marketers were facing one constraint or the other which hinder the free flow of their market to the final consumers. These constraints include poor sale price, high production cost, low patronage, insufficient fund, poor handling, packaging and processing facilities, lack of capital, inadequate storage facilities, lack of price stability and small enterprise with low earnings. This finding is in tandem with the findings of Babalola et al. (2015) who identified the high cost incurred in preserving the fishes, huge initial expense, price instability, inconsistent and high transport cost while carrying out research on economic potentials of fish marketing and women empowerment in Ogun State. In the same vein, Ashiru (2011) identified lack of capital, price instability, poor handling, packaging and processing. Inadequate operating capital, transport and market information were reported as major constraints to fish marketing system in Ibarapa zone. Others are: scarcity of feeds, inadequate training and insufficient supply of fingerlings (Banjo et al., 2009).

Similarly, lack of capital was found to be significant but negatively correlated with fish marketing in the study site. This outcome implies that as much as the fish marketers continue to suffer from capital dwindling, the likelihood of boosting their sales becomes waning. It is somewhat rational considering the fact that every business needs increased fund to thrive particularly in a highly competitive marketing system. 
This result agrees with Omeje et al. (2020) who posited that capital is needed to purchase land, feed, construct ponds, buy drugs etc. hence, capital is considered sine qua non to fish farming.

Furthermore, marketing of fish in Ido LGA, Oyo State was profitable having a gross margin of 5.057 while the profitability index was 0.057 . This outcome implies that for every 1,000 spent on fish marketing, N57 was realized as profit. Thus, fish marketing in the study area was profitable though with mild profit margin. The outcome therefore conforms to Ashiru (2011) who noted that fish farmers get little return from their businesses due to the interference of middlemen activities. It can be deduced that the most fish marketers stocked their fish from the middle men as this might be responsible for the low profit margin among other constraints.

This result agrees with the findings of Awe et al. (2012) on Irvingia kernels marketing in Akure, Ondo State which returned $¥ 650$ as profit on every $\$ 1,000$ cost price expended by the sellers. Likewise, the study gave a robust backing for comparable researches by Azeez et al. (2011; 2015) using similar methodology for different merchandises (woodcraft and fuel wood enterprises) where a sum of $\$ 100$ and $\$ 750$ (investment worth) were realized, respectively for every $\$ 1,000$ spent on the total investments. In contrast, there was a marketing inefficiency of fresh fish (Clarias gariepinus) marketing system in major towns of Ibarapa zone, Oyo State, Nigeria (Ayanboye et al., 2015).

\section{CONCLUSION}

In this paper, we analyzed factors influencing fish marketing in the study area using multiple regression models. Moreover, we evaluated various challenges facing the fish marketers; the marketing channels adopted; the cost, the revenue and the marketing margin of fish marketing in Ido LGA, Oyo State. The study concluded that age, level of education, lack of capital, high cost of production and access to credit facilities were the factors influencing the participation of rural households in fish marketing in Ido LGA. It also concluded that fish marketing was a profitable business but with a minor profit margin. Furthermore, the constraints identified were lack of capital, price instability and poor handling, packaging and processing.

\section{RECOMMENDATIONS}

Based on the findings of this study, some recommendations are made. Since it was discovered in the course of the study that fish sellers encountered some constraints that somehow bothered on poor handling, processing and packaging of fish products, it is hereby recommended that government should, as a matter of policy intervention, subsidize the cost of procuring necessary technology (machines) that will remove virtually most of the constraints being faced by the fish marketers as against the tedious traditional processing methods hitherto being used by the marketers.
Arising from the fact that fish marketing was a lucrative business in the study area, Government should make the business more attractive through its various value chains to improve its sustainability. Likewise, policy measure such as micro lending programmes should be given a needful attention and priority to increase the entrepreneurs' income and brings about a massive economic prospect for Ido LGA in particular and Oyo State Nigeria in general.

\section{REFERENCES}

Agbelege O.O. and Ipinjolu J.K. (2013). An assessment of the management techniques of the fisheries resources in the Nigerian portion of Lake Chad. J. Arid Zone Fishery, 1, 89-98

Ashiru M.A. (2011). Economic Analysis of Fish Farming and Its Contribution to Household Poverty Alleviation in Akure South and Owo Local Government Areas of Ondo State, Nigeria. Thesis for MSc in Agric. Econs., Ahmadu Bello University, Zaria, Nigeria, pp 40-42

Atanda A.N. (2009). Freshwater fish feed resources in Nigeria. Fish Network, 5 (4) 26-57

Awe F., Imoagene E., Osadebe C.O., Azeez F.A. and Eniola T.S. (2012). Evaluation of irvingia kernels marketing in selected markets in Akure, Ondo State, Nigeria. Int. J. Agric. Forestry, 2 (3), 113-116

Ayanboye A.O., Oluwafemi Z.O. and Rafiu R.A. (2015). Fresh fish (Clarias gariepinus) marketing system in major towns of Ibarapa Zone, Oyo State, Nigeria. Int. J. Appl. Agric. Apicultural Res., (1 \& 2), 162-171

Ayoola S.O. (2010). Sustainable fish production in Africa. Afr. J. Food Agric. Nutr. Dev., 10 (5), 1-9

Azeez F.A., Ojo O.B., Onajobi A.A., Ajibola A.O. and Amoo M.A. (2011). Wood craft enterprises participation and return analysis in Oyo State. J. Ecol. Natural Environ., 3 (10), 332-336

Azeez F.A., Ajayi C.A., Olarewaju T.O., Nosiru M.O. and Farinola L.A. (2015). The utilization pattern and economic evaluation of fuel wood enterprise: A case study of some areas in Ibadan metropolis, Oyo State. Int. J. Agric. Forest. Fisheries, 2 (6), 91

Babalola D.A., Bajimi O. and Isitor S.U. (2015). Economic potentials of fish marketing and women empowerment in Nigeria: Evidence from Ogun State. Afr. J. Food, Agric. Nutr. Dev., 15 (2), 9923-9934

Banjo O.S., Nosiru M.O., Ayorinde B.J.O. and Odusina O.A. (2009). Improving clarias productivity towards achieving food security in Ijebu-Ode, Ogun State, Nigeria: A socioeconomic analysis. Adv. Biol. Res., 3 (1-2), 24-28

Nwabunike M.O. (2015). Cost benefit of smoked fish marketing within Abakaliki metropolis. Int. J. fisheries and aquatic studies, 2 (4), 345-349

Olagunju F.I., Adesiyan I.O. and Ezekiel A.A. (2007). Economic viability of catfish production in Oyo State, Nigeria. J. Human Ecol., 21 (2), 121-124

Olayemi J.K. (1998). Food Security in Nigeria. Ibadan: Development Policy Centre.

Olukosi J.O., Isitor S.U. and Ode M.O. (1990). Introduction to Agricultural Marketing and Prices; Principles and Application. Living Book Series, G.U. Publication Abuja, Nigeria, pp. 37-47

Omeje J.E., Sule A.M. and Aguihe E.O. (2020). An assessment of aquaculture table-size fish farmers activities in Kainji Lake Basin, Nigeria. Agro-Science, 19 (2), 36-40

Pala A.O. (1976). African Women in Rural Development Research, Trends and Priorities. Overseas Liason Committee, Afr. Council on Edu. Paper 12, pp. 5-8 